\title{
PREVALENCE OF ECHINOCOCCUS GRANULOSUS IN DIFFERENT INTERMEDIATE HOSTS IN DUHOK PROVINCE, KURDISTAN REGION, IRAQ
}

\author{
Azad Abdullah Meerkhan ${ }^{\mathrm{a}}{ }^{*}$, Jassim M. Abdo ${ }^{\mathrm{b}}$, Wijdan M. Salih', Adriano Casulli ${ }^{\mathrm{d}}$ \\ ${ }^{a}$ Dept. of Pharmacy, Duhok Technical Institute, Duhok polytechnic University, Kurdistan Region - Iraq \\ ${ }^{b}$ Duhok Veterinary Researcg Centerm University of Duhok, Kurdistan Region - Iraq. \\ 'Dept. of Biology, Faculty of Science, University of Zakho, Kurdistan region, Iraq. \\ ${ }^{\mathrm{d} D e p t . ~ o f ~ I n f e c t i o u s, ~ P a r a s i t i c ~ a n d ~ I m m u n o-m e d i a t e d ~ D i s e a s e s, ~ I s t i t u t o ~ S u p e r i o r e ~ d i ~ S a n i t a, ~ R o m e ~-~ I t a l y . ~}$
}

\begin{abstract}
:
This study was carried out in Duhok provinces, Kurdistan Region/ Iraq from August; 2014 to December 2015.The study focused on the prevalence of CE in slaughtered animals. The total prevalence was 5.25\% (11753/223436), with a high rate in sheep (4.25\%), and low rates in goats and cattle $(0.64 \%$ and $0.37 \%$, respectively). With respect to abattoirs involved in the study, the highest prevalence was detected in Akre abattoir (8.21\%) and the lowest in Amedy abattoir (4.09\%). Among the infected animals, sheep in Akre abattoir recorded the highest prevalence, while cattle in Duhok abattoir recorded the lowest prevalence $(7.57$ and $0.1 \%$, respectively). Males of sheep, goats and cattle showed higher prevalence $(70.51,63.62$, and $92.06 \%$, respectively). Regarding organ involvements, malesand females of cattle showed high liver involvement $(63.13$ and $84.62 \%$, respectively), while males and females of sheep (62.21 and $60.31 \%$, respectively) and goats (60.59 and $54.51 \%$, respectively) showed high lungs involvements.
\end{abstract}

KEYWORDS: Hydatidosis; Cystic Echinococcosis; Echinococcus Granulosus Senso Lato; Cyst Location; Organ Involvements; Kurdistan-Iraq.

\section{INTRODUCTION}

Cystic echinococcosis (CE) is caused by the larval stage of Echinococcus granulosus senso lato which adult stages inhabits the intestine of canids is one of the most important parasitic zoonoses of worldwide distribution, including Europe, Central Asia, China, Australia, Northern Africa, South America, Middle East, and Iran (Schmidt and Roberts, 2000) affecting domesticated, wild mammals and humans (Deplazes et al., 2017).

In Iraq, Hydatidosis has been reported since 1940 by Senekji and Beattie (1940) who undertook the first comprehensive study on echinococcosis on stray dogs from Baghdad. In addition, Babero et al. (1963) observed echinococcal cysts in sheep, cows, buffaloes and camels, and reported that stray dogs captured in Baghdad and other cities harbored adult worms. Baban (1990), during his study on human hydatidosis, recorded this disease in three governorates (Diala, Karkuk, and Thaiqar) with different prevalence rates. Al-Fatalawei (2002), in a study in Al-Qadisia governorate, revealed a prevalence of $20.59 \%$ in cattle, sheep and goats slaughtered at AL-Dewania abattoir. AlAni (2012), in a study on different regions of Baghdad recorded a prevalence of $9.9 \%$ in examined animals.

Regarding Kurdistan region, several studies reported variable prevalence rates of hydatidosis in domestic animals from Duhok province abattoir (Ghaffar, 2008;Abdullah, 2009;Meerkhan,2011;Meerkhan and Abdullah,2012;Meerkhan and Mero,2013). In Erbil, province (Molan and Saida, 1989; Al-Barwari et al., 1991; Saeed et al., 2000; Hassan et al., 2016) and Sulaimani province (Bajalan, 2006; Hama et al., 2015).

The present study aims at the identification of the CE prevalence and the its relation with gender and cyst location in unstudied areas of Duhok province such as, Duhok city, Zakho,
Summel, Akre, Bardarash, Amedi and Shekhan, Duhok Province, Kurdistan Region of Iraq.

\section{MATERIAL AND METHODS}

From August; 2014 to December 2015. The official records of the Duhok Veterinary Directorate were checked for data from abattoirs of Duhok, Zakho, Akre, Bardarash and Amedy. Number of the slaughtered sheep, goats and cattle (the infected and un-infected animals) were counted, and the prevalence of the infection, was calculated for each of them and linked with the animal gender and cyst location.

\section{RESULTS}

During the study period, 223,436 animals (sheep, goats and cattle) were slaughtered in the five official abattoirs (Table1) recording $11,753(5.26 \%) \mathrm{CE}$ cases in animals. The highest prevalence $(8.21 \%$ ) was recorded from Akri abattoir, while the lowest prevalence (4.09\%)in Amedy abattoirs. Among the intermediate hosts, sheep had the highest infection rate while cattle had the lowest rate $(4.25 \%$ and $0.37 \%$, respectively) as shown in Table 2 .

Table 1. The prevalence of cystic echinococcosis among slaughtered animals in different abattoirs

\begin{tabular}{cccc}
\hline \multirow{2}{*}{ Abattoirs } & \multirow{2}{*}{ Slaughtered } & \multicolumn{2}{c}{ Infected } \\
\cline { 3 - 4 } & & No. & $\%$ \\
\hline Duhok & 137,475 & 6,223 & $4.53 \%$ \\
Zakho & 33,076 & 1,668 & $5.04 \%$ \\
Akre & 31,780 & 2,608 & $8.21 \%$ \\
Bardarash & 12,039 & 883 & $7.33 \%$ \\
Amedy & 9,066 & 371 & $4.09 \%$ \\
Total & 223,436 & 11,753 & $5.26 \%$
\end{tabular}

\footnotetext{
${ }^{*}$ Corresponding Author

This is an open access under a CC BY-NC-SA 4.0 license (https://creativecommons.org/licenses/by-nc-sa/4.0/)
} 
Table 2. The prevalence of cystic echinococcosis among slaughtered animals in different hosts

\begin{tabular}{cccccccc}
\hline \multirow{2}{*}{ Abattoir } & \multirow{6}{c}{ Infected Animals } \\
\cline { 2 - 8 } & \multirow{2}{*}{ Total1 } & \multicolumn{2}{c}{ Sheep } & \multicolumn{2}{c}{ Goats } & \multicolumn{2}{c}{ Cattle } \\
\cline { 2 - 8 } & & No. & $\%$ & No. & $\%$ & No. & $\%$ \\
\hline Duhok & 137,475 & 5413 & 3.94 & 677 & 0.49 & 133 & 0.10 \\
Zakho & 33,076 & 1127 & 3.41 & 484 & 1.46 & 57 & 0.17 \\
Akre & 31,780 & 2407 & 7.57 & 131 & 0.41 & 70 & 0.22 \\
Bardarash & 12,039 & 342 & 2.84 & 15 & 0.12 & 526 & 4.37 \\
Amedy & 9,066 & 213 & 2.35 & 125 & 1.38 & 33 & 0.36 \\
Total & 223,436 & 9,502 & 4.25 & 1,432 & 0.64 & 819 & 0.37 \\
\hline
\end{tabular}

Prevalence of CE infection of different intermediate hosts (Table.3) was $5.26 \%$, with the highest prevalence $(10.6 \%)$ of sheep was in Akri abattoir, while the lowest prevalence (5.24 $\%)$ was in Duhok abattoir, the highest prevalence in goats (5.55\%) was reported in Duhok abattoir and the lowest $(2.74 \%)$ was in Akri abattoir. Regarding cattle, the highest prevalence $(8.01 \%)$ was from Bardarash abattoir and the lowest $(0.61 \%)$ in Duhok abattoir.

Table 3. The prevalence of cystic echinococcosis among slaughtered animals in different intermediate hosts

\begin{tabular}{ccccc}
\hline \multirow{2}{*}{ Abattoirs } & \multirow{2}{*}{ Host } & \multirow{2}{*}{ Slaughtered } & \multicolumn{2}{c}{ Infected } \\
\cline { 3 - 5 } Duhok & Sheep & 103374 & 5413 & $5.24 \%$ \\
& Goats & 12209 & 677 & $5.55 \%$ \\
& Cattle & 21892 & 133 & $0.61 \%$ \\
\multirow{5}{*}{ Zakho } & Sheep & 20808 & 1127 & $5.42 \%$ \\
& Goats & 7608 & 484 & $6.36 \%$ \\
& Cattle & 4660 & 57 & $1.22 \%$ \\
\multirow{5}{*}{ Akre } & Sheep & 22698 & 2407 & $10.6 \%$ \\
& Goats & 4776 & 131 & $2.74 \%$ \\
& Cattle & 4306 & 70 & $1.63 \%$ \\
& Sheep & 5128 & 342 & $6.67 \%$ \\
& Goats & 347 & 15 & $4.32 \%$ \\
& Cattle & 6564 & 526 & $8.01 \%$ \\
& Sheep & 2894 & 213 & $7.36 \%$ \\
& Goats & 2043 & 125 & $6.12 \%$ \\
& Cattle & 4129 & 33 & $0.8 \%$ \\
& & 223436 & 11753 & $5.26 \%$ \\
\hline
\end{tabular}

Regarding the gender, male sheep, goats and cattle, showed higher prevalence $(70.51 \%, 63.62 \%$ and $92.06 \%$, respectively) (Table.4).

Table 4. The prevalence of cystic echinococcosis among slaughtered Animals according to gender.

\begin{tabular}{|c|c|c|c|c|c|c|c|}
\hline \multirow{3}{*}{ Host } & \multirow{3}{*}{ Slaughtered } & \multicolumn{6}{|c|}{ Infected Animals } \\
\hline & & \multicolumn{2}{|c|}{ Total } & \multicolumn{2}{|c|}{ Male } & \multicolumn{2}{|c|}{ Female } \\
\hline & & No. & $\%$ & No. & $\%$ & No. & $\%$ \\
\hline Sheep & 154902 & 9502 & 6.13 & 6700 & 70.51 & 2802 & 29.49 \\
\hline Goats & 26983 & 1432 & 5.31 & 911 & 63.62 & 521 & 36.38 \\
\hline Cattle & 41551 & 819 & 1.97 & 754 & 92.06 & 65 & 7.94 \\
\hline Total & 223436 & 11753 & 5.26 & 8365 & 71.17 & 3388 & 28.83 \\
\hline
\end{tabular}

With respect to infected organs, lungs had a higher prevalence in both sheep and goats (61.65 and $58.38 \%$, respectively), while in cattle; liver had the higher prevalence $(64.84 \%)$. The lowest prevalence $(0.17 \%)$ of infection was reported in kidneys of slaughtered animals with the highest $(0.98 \%)$ being in cattle (Table. 5). Regarding the gender, both males and females of sheep and goats had high prevalence in lung and both sexes of cattle had high prevalence with liver involvements (Table.6).
Table 5. The prevalence of cystic echinococcosis among slaughtered animals according to organ involvement

\begin{tabular}{cccccccc}
\hline \multirow{3}{*}{ Host } & \multicolumn{7}{c}{ Infected Animals } \\
\cline { 2 - 8 } & \multirow{2}{*}{ Total } & \multicolumn{2}{c}{ Liver } & \multicolumn{2}{c}{ Lungs } & \multicolumn{2}{c}{ Kidneys } \\
\cline { 2 - 8 } & & No. & $\%$ & No. & $\%$ & No. & $\%$ \\
\hline Sheep & 9502 & 3634 & 38.24 & 5858 & 61.65 & 10 & 0.11 \\
Goats & 1432 & 594 & 41.48 & 836 & 58.38 & 2 & 0.14 \\
Cattle & 819 & 531 & 64.84 & 280 & 34.19 & 8 & 0.98 \\
Total & 11753 & 4759 & 40.49 & 6974 & 59.34 & 20 & 0.17 \\
\hline
\end{tabular}

Table 6. The prevalence of cystic echinococcosis in different organs among slaughtered animals and their relation to hosts gender

\begin{tabular}{lllcccccc}
\hline \multirow{3}{*}{ Host } & \multirow{2}{*}{ Gender } & \multicolumn{6}{c}{ Infected Animals } \\
\cline { 3 - 9 } & & \multirow{2}{*}{ Total } & \multicolumn{2}{c}{ Liver } & \multicolumn{2}{c}{ Lungs } & \multicolumn{2}{c}{ Kidneys } \\
\cline { 3 - 9 } Sheep & No. & $\%$ & No. & $\%$ & No. & $\%$ \\
\hline \multirow{5}{*}{ Goats } & Male & 6700 & 2525 & 37.69 & 4168 & 62.21 & 7 & 0.10 \\
& Female & 2802 & 1109 & 39.58 & 1690 & 60.31 & 3 & 0.11 \\
& Male & 911 & 358 & 39.3 & 552 & 60.59 & 1 & 0.11 \\
& Femalte & 521 & 236 & 45.3 & 284 & 54.51 & 1 & 0.19 \\
& Male & 754 & 476 & 63.13 & 270 & 35.81 & 8 & 1.06 \\
& Female & 65 & 55 & 84.62 & 10 & 15.38 & 0 & 0 \\
\multicolumn{2}{c}{ Total } & 11753 & 4759 & 40.4 & 6974 & 59.34 & 20 & 0.17 \\
\hline
\end{tabular}

\section{DISCUSSION}

Cystic echinococcosis is endemic in many parts of world and is the cause of serious health concern. The incidence differs according to the host, the infected organ, the gender and the geographic regions (Al-Fatalawi, 2002; Tashani et al., 2002; Eckert and Deplazes, 2004; Mohsen et al., 2009; Meerkhan and Abdullah, 2012). In Kurdistan Region, several factors contribute to the transmission of the infection, including cultural, educational, socioeconomical conditions.

The highest prevalence of CE was in sheep, this is in agreement with the results of Saida and Nouraddin (2011), Al-Berwari (2012); Meerkhan and Abdullah (2012); Hama (2013) and AlBosely (2014). In all these studies the highest prevalence of infection was in sheep although the prevalence rate was fluctuating. Such results indicate the high susceptibility of sheep to this parasite. In addition the molecular studies performed in Kurdistan proved that the sheep strain (G1 genotype) is the most prevalent in this area (Ahmad et al., 2013 and Hama et al., 2013).

The low prevalence of CE in goats and cattle are in accordance to the findings of Bajalan (2006) in Kalar, Kadir and Rasheed (2008) in Kurkuk and Mero et al. (2014) in Sulaimani. All these authors attributed the low prevalence to the feeding habit of goats, as they eat the higher parts of herbage that are exposed to the sunlight which decrease the viability of the parasite eggs, in addition it is difficult for dogs to uphill to these area for the defecation. The low prevalence in cattle may be due to rearing them in cowshed with better care which relatively contact with dogs (Thompson and McManus, 2002).

Regarding the gender, male sheep, goats and cattle, showed higher prevalence $(70.51 \%, 63.62 \%$ and $92.06 \%$ respectively) than females, in this aspect the present results contradict with other studies involving the same intermediate host, as most of them reported higher prevalence in females (Daryani et al., 2007, in Iran; Kamhawi et al., 2009 in Jordan; Hama, 2013, and Sargali and Mero, 2013, in Iraq). While Mero et al. (2014) in Sulaimani province, found that the sex of the slaughtered animals has no significant effect on the distribution of CE, as the prevalence in males and females sheep, goats and cattle were very closed. In the present study, the highest prevalence of infection in males might be due to either the high number of slaughtered males of each species(Table.6) which was almost the twice of females, or they may be older in age.

Highest prevalence of CE was in the liver and the lungs, this is in agreement with the results of Ibrahim (2010), Hama (2013), Sargali and Mero (2013), AL-Bosely (2014), Mero et al. 
(2014). This is because the liver act as the first filter for larval infection and the lungs as the second filter, and the oncosphere adopt the portal vein route and primarily negotiate hepatic and pulmonary filtering system sequentially before any other peripheral organ is involved (Kebede et al., 2009; Khalf et al., 2014; Mero et al., 2014; and Temam et al., 2016).

\section{REFERENCES}

Abdullah, A. M (2009). Epidemiological, Comparative Enzymatic and Total Protein content of Hydatid cyst of Echinococcusgranulosus isolated from Sheep and Goats in Duhok province, Kurdistan Region of Iraq, M. Sc. Thesis, College of Education.,University of Duhok.

Al-Ani, W. A. T.(2012). Hydatidosis of slaughtered sheep in Baghdad City; bacteriological study of infected hydatid cyst fluid. Mustansiriya Medical Journal, 11. 45-48.

Al-Barwari, S.E.; Saeed, I.S.; Khalid, W. and Al-Harmni, K. I. (1991). Human hydatidosis in Arbil, N. Iraq. Journal of Islamic Academy of Sciences. 4. 330-335.

AL-Bosely, A. R. I. (2014). Studies on epidemiology of hydatid cysts isolated from different intermediate hosts in Zakho, Duhok province, Kurdistan region, Iraq. M. Sc. Thesis, Faculty of Science. University of Zakho.

Al-Fatalawei, M.A.A. (2002). Epidemiological and biological study of hydatidosis in Al-Qadisia governorate. M.Sc. Thesis, College of Veterinary Medicine, University of Baghdad, Iraq.

Baban, M. R. A. (1990). Study on epidemiology of hydatid cysts in AlTameem, Dyala and Thi-Qar. M.Sc. Thesis. College of Education, Salahaddin University.

Babero, B. B.; Al-Dabagh, M. A.; Al-Saffar, A. S. and Frozan, M. A. (1963). The Zoonosis of Animal Parasites in Iraq. XII. The Dog as a Reservoir for Human Cestode Infections. J. Fac. Meet., 5: 149-58.

Bajalan, M.M. (2006). Prevalence of Echinococcosis in stray dogs and slaughtered livestock in Kalar district/Sulaimaniyah province/Kurdistan Iraq. M. Sc. Thesis, College of Veterinary Medicine, Univ. of Baghdad.

Casulli, A.; Manfredi, M. T.; La Rosa, G.; Cerbo, A. R.;Genchi, C. and Pozio, E. (2008). Echinococcusortleppiand E. granulosus G1, G2 and G3 genotypes in Italian bovines. Vet. Parasitol., 155: $168-72$.

Daryani, A.; Alaei, R. ; Arab, R. ; Sharif, M.;Dehghan, M. H. and Ziaei, H. (2006). Prevalence of Hydatid Cyst in Slaughtered Animals in Northwest Iran. Journal of Animal and Veterinary Advances, 5. 330-334

Deplazes P; Rinaldi, L.; Alvarez Rojas, C.A.; Torgerson, P.R.; Harandi, M.F.; Romig, T.; Antolova, D.; Schurer, J.M.; Lahmar, S.; Cringoli, G.; Magambo ,J.; Thompson, R.C. and Jenkins, E.J. (2017) Global Distribution of Alveolar and Cystic Echinococcosis. .Adv. Parasitol., 95:315-493.

Eckert, J and Thompson, RCA. (1997).Intraspecific variation of Echinococcusgranulosus and related species with emphasis on their infectivity to humans. Acta Tropica. 64: 19-34.

Eckert, J. and Deplazes, P. (2004). Biological, epidemiological, and clinical aspects of echinococcosis, a zoonosis of increasing concern. Clin. Microbiol. Rev., 17: 107-35.

Ghaffar, N. M. (2008). Prevalence of hydatidosis in livestock slaughtered at Duhok abattoir of Kurdistan Region of Iraq M.Sc. Thesis Coll.ofVet.Med.Univ.ofDohuk.

Hama, A. A. (2013). Epidemiological study and molecular characterization of Echinococcus granulosus in Suleimani province Kurdistan- Iraq. PhD. Thesis. Faculty of Science, Zakho University.

Hama, A. A.; Hassan, Z. I.; Salih Mero, WM.; Interisano, M.; Boufana, B. and Casulli, A. (2015). A morphologically unusual Echinococcus granulosus (G1 genotype) cyst in a cow from Kurdistan-Iraq. Epidemiology (sunnyvale), 5: 2161-1165.

Hassan, Z. I.; Mero, W. M. S.; Casulli, A.; Interisano, M., and Boufana, B. (2016). Epidemiological Study of Cystic Echinococcosis In Sheep, Cattle and Goats In Erbil Province, JUOZ, 4 A-S: 43

Ibrahim, M. M. (2010). Study of cystic echinococcosis in slaughtered animals in Al Baha region, Saudi Arabia: interaction between some biotic and abiotic factors. Acta Tropica. 113: 26-33.
Kadir, M. A., and S. A. Rasheed. (2008). "Prevalence of some parasitic helminths among slaughtered ruminants in Kirkuk slaughter house, Kirkuk, Iraq." Iraqi J. Vet. Sci., 22.2: 81-85.

Kamhawi, S.; Hijjawi, N.; Abu-Ghazaleh, A.; Abbas, M.; (2009): Prevalence of hydatid cysts in livestock from five regions in Jordan. Ann. Trop. Med. Parasitol., 89: 621-629.

Kebede, N.; Mekonnen, H.;Wossene, A., and Tilahun, G. (2009). Hydatidosis of slaughtered cattle in WolaitaSodo Abattoir, southern Ethiopia. Trop. Anim. Health Prod., 41: 629-33.

Khalf, M.S; Al-Faham, M.A.; Al-Taie, L.H., and Alhussian, H.A. (2014). Genotyping of Echinococcusgranulosusin Samples of Iraqi Patients. IOSR Journal of Pharmacy and Biological Sciences, 9: 06-10.

Meerkhan, A. A. (2011). Biochemical studies on hydatid cysts of Echinococcusgranulosus isolated from different intermediate host (sheep, goat, cows and human). M. Sc. Thesis, College of Education, University of Zakho, Iraq

Meerkhan, A. A. and Abdullah, A. M. (2012). The epidemiology of hydatidosis in different slaughtered animals in Duhok abattoir, Kurdistan Region of Iraq Second international conference. Bali (Indonesia).4: 45-48.

Meerkhan, A. A. and Mero, W. M.S. (2013). Determination of lipids and glucose content in hydatid cysts of Echinococcusgranulosus isolated from different intermediate hosts (sheep, goats, cattle and human) tissues.JUOZ,1A, 1:50-57

Mero, W.M.S.; Jubrael, J.M.S., and Hama, A.A.(2014) Prevalence of Hydatid Disease among slaughtered animals in Slemani Province/ Kurdistan-Iraq. JUOZ, 2: 33-38.

Mohsen, S. S.; Jiyad, A. L.; and Mohamad, R. N. (2009) Genetic Variation for epidemiological human Echinococcusgranulosus from different regions of Iraq. AL-Qadisiya Journal of Veterinary Medicine Science, 8: $55-62$.

Molan, A. L., and Saida, L. A. (1989). Echinococcosis in Iraq: Prevalence of Echinococcus granulosus In Stray Dogs in Arbil Province. Japanese Journal of Medical Science and Biology, 42: 137-141.

Romig, T. (2003). Epidemiology of echinococcosis. Langen becks Arch Surg., 388: 209-17.

Saeed, I.; Kapel, C.;Saida, L.A.; Willingham, L. and Nansen, P. (2000) Epidemiology of Echinococcusgranulosus in Arbil province, northern Iraq, 1990-1998. Journal of helminthology. 74: 83-88.

Saida, L. A., andNouraddin, A. S. (2011) "Epidemiological study of cystic echinococcosis in man and slaughtered Animals in Erbil province, Kurdistan Regional-Iraq." Tikrit Journal of Pure Science, 16 (4) : 45-50

Sargali, A. A and Mero, W. M.S.(2013).Epidemiological Study of Hydatid Cyst of Echinococcus granulosus Isolated from Sheep and Goats in Duhok Province, Kurdistan Region of Iraq. J.U.O Z., 1 A: 38-43.

Schmidt, G.D., and Roberts, L.S. (2000). Tapeworms (Chapter 21), ed. Foundations of parasitology. Mosby College Publishing, 41

Senekji, H. A., and Beattie, C.P. (1940). The incidence of hydatid disease in Iraq. Transactions of the Royal Society of Tropical Medicine and Hygiene. 33: 461-462.

Tashani, O.A, Zhang, L.H.; Boufana, B.:Jegi, A., and McManus, D.P. (2002). Epidemiology and strain characteristics of Echinococcus granulosus in the Benghazi area of eastern Libya. Annals of Tropical Medicine \& Parasitology, 96: 369-381.

Temam, B. D., and Mukarim, A. A. (2016). Study on Prevalence and Monetary Loss Attributed to Hydatidosis in Cattle Slaughtered at Jimma Municipal Abattoir, Southwestern Ethiopia. Global Journal of Medical Research. 16.

Thompson, R.C. A., and McManus, D. P. (2002). Towards a taxonomic revision of the genus Echinococcus. Trends in Parasitology. 18. 452-457. 